\title{
METHODS FOR MONITORING ALPINE PLANT PHENOLOGY: A PILOT STUDY IN THE LINE CREEK PLATEAU RESEARCH NATURAL AREA, USA
}

\author{
ZDENKA KŘENOVÁ ${ }^{1, *}$, J. STEPHEN SHELLY2, \\ and ZDEŇKA CHOCHOLOUŠKOVÁ 3

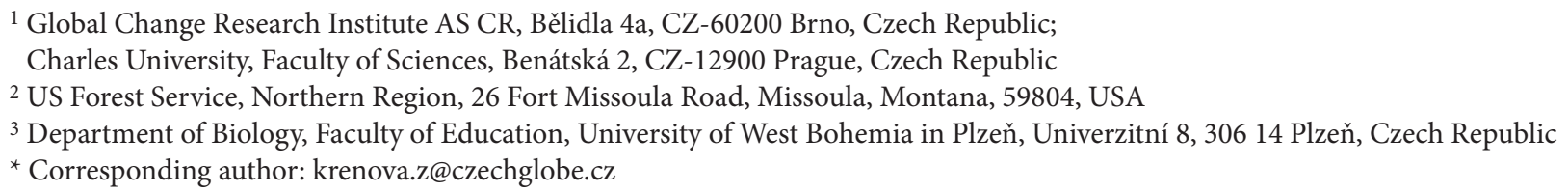

\section{ABSTRACT}

\begin{abstract}
Alpine plant phenological traits are studied and several hypotheses about their latitudinal variation are tested within a comparative research project, which is being conducted on groups of plant species for which relationships are inferred from available phylogenies. The study sites for this project are located in tropical Ecuador, semitropical Bolivia and the temperate Rocky Mountains in the USA. Several temperate alpine species occur near the Rocky Mountains Field Station in Colorado and large populations of three alpine target species (Caltha leptosepala Castilleja pulchella, Gentiana algida) were found at the Line Creek Plateau Research Natural Area, in the Beartooth Range in Montana. This location was initially investigated in August 2018 to choose the study site and test a methodology for collecting plant trait data. This study site, the target plant species and the results of a preliminary study, together with recommendations for the full season monitoring, are discussed in this paper.
\end{abstract}

Keywords: alpine plants; Caltha; Castilleja; climate change; Gentiana; reproductive ecology

\section{Introduction}

Many measurements as well as various climate scenarios indicate that climate is warmer and drier during last decades. Alpine habitats are one of the most threatened due to their island distribution. Better understanding of the phenology and reproductive strategies of alpine plants growing in alpine areas in both the tropics and temperate regions can be used to determine how functional traits respond to the different selective pressures of alpine environments.

It is suggested that the remarkable plant radiation in alpine areas in the tropics may be related to their "escape" from the stress of a seasonal temperate climate (Pfitsch 1994). Whereas growth of alpine plants in temperate regions is limited to the summer period (Körner 2003), the continuous growing season prevailing at high altitudes in the tropics may have released them from the constraints imposed by a seasonal climate. For instance, there is no need for a rapid development of flowers and fruits, and observations of tropical alpine communities in Ecuador (Kolář et al. 2016; Sklenár 2017) indicate that plant phenology is less constrained temporarily than in the temperate zone. Moreover, given the low probability of encountering severe freezing temperatures (below $-10{ }^{\circ} \mathrm{C}$ ) during the growing season in the humid tropics, selection for pronounced freezing resistance is less likely in tropical alpine plants. This is supported by data on plant tolerance of freezing measured in Venezuela, Ecuador, the Rocky Mountains (USA) and Giant Mountains (Czech Republic) (Sklenář et al. 2012, 2016).
Functional plant traits are defined as morpho-physio-phenological traits that impact the fitness of individual species via their effects on growth, reproduction and survival, the three components of individual performance (Violle et al. 2007). Moreover, functional traits can indicate how a species relates and responds to its environment, which offers a powerful approach to addressing ecological questions (McGill et al. 2006). The alpine plant traits are studied and several hypotheses about their latitudinal variation are tested within the project "Evolution of functional traits of alpine plants in temperate and tropical environments", granted by the Czech Grant Agency (Grant number 17-12420S). The most important and novel point of this project is that the comparative research is carried out on species and species groups of plants for which relationships are inferred from available phylogenies. In addition to the above, the species groups meet the following criteria: i) they have the same growth form and ii) they occur in equivalent habitats in the compared regions. The following plant groups are studied:

- Caltha - the North American species C. leptosepala is sister to a clade of South American species, including C. sagittata, which occurs both in Ecuador and Bolivia (Schuettpelz and Hoot 2004).

- Cerastium - the species pair C. arvense - C. arvensiforme is studied, which are sometimes considered conspecific. The South American species of Cerastium are derived from a North American clade, which supports a north-to-south migration (Sheen et al. 2004).

- Castilleja - perennial species are sampled, i.e., South American C. nubigena along with some North Amer- 
ican perennial Castilleja species. The South American species are sister to meso-American species and together they are sister to North American species (Tank and Olmstead 2008).

- Gentiana - Perennial G. algida from temperate regions is compared with the supposedly perennial G. sedifolia and perennial Gentianella punicea (Holub 1967) in the Andes.

- Valeriana - Herbaceous species forming a basal leaf rosette and growing in similar alpine habitats.

The study sites are located in tropical Ecuador and semitropical Bolivia. Several temperate species occur near the Rocky Mountains Field Station in Colorado, USA (Fowler et al. 2014; Sklenár pers. comm.), and large populations of other target species (Caltha leptosepala, Castilleja pulchella, Gentiana algida) were found at the Line Creek Plateau Research Natural Area in Montana, USA, in August 2018. Information on the latter study site and results of a preliminary study, including recommendations for a full season of phenology monitoring, are presented in this paper.

\section{Methodology}

\section{Study area}

The Line Creek Plateau Research Natural Area (RNA) is one of over 530 RNAs established by the U.S. Forest Service. This national network of protected areas provides sites for research, education, monitoring, and the conservation of biological diversity. The RNAs established to date include a wide range of vegetation types that occur on the national forests and grasslands in the United States (Evenden et al. 2001).
The Line Creek Plateau RNA was established in 2008. The total area is 22,422 acres (9,074 ha), making it the largest RNA established by the US Forest Service. Most of the RNA (19,369 acres) is located in the Beartooth Ranger District, Custer-Gallatin National Forest, Montana, with a smaller part (3,053 acres) in the Clark's Fork Ranger District of the Shoshone National Forest in $\mathrm{Wy}-$ oming (Fig. 1).

Line Creek Plateau is the easternmost alpine area in the Beartooth Mountains. Elevations in the RNA range from 7,400 feet (2,256 metres) to 10,892 feet (3,321 metres). Gently rolling alpine tundra and turf are predominant on the top of the plateau, and cover approximately 9,750 acres $(3,948$ ha) in the RNA. Nine alpine plant community types (c.t.) are represented, with three types being the most prevalent: Festuca idahoensis/Geum rossii c.t., Carex elynoides c.t., and Carex scirpoidea/Geum rossii c.t. Most of the remaining acreage in the RNA is dominated by forested plant communities, including Pinus albicaulis, P. flexilis, Abies lasiocarpa, and Pseudotsuga menziesii. There are two plant communities dominated by willow species in the Montana portion of the RNA: Salix glauca/Deschampsia cespitosa c.t. and Salix planifolia/Carex paysonis c.t. Soils of the RNA are derived from hard, coarse-grained metamorphic rocks (mostly gneiss and granite), and range from well-drained loams to sands. The average temperature on Line Creek Plateau is $9-11{ }^{\circ} \mathrm{C}$, with an average low temperature of $-2{ }^{\circ} \mathrm{C}$ and an average high temperature of $21-23^{\circ} \mathrm{C}$. The plateau receives an average of $1,016 \mathrm{~mm}$ of precipitation annually, predominantly in the form of snow (USDA Forest Service 2001).

Part of the study site for the three target species occurs in the community types with Geum rossii (Castilleja pul-

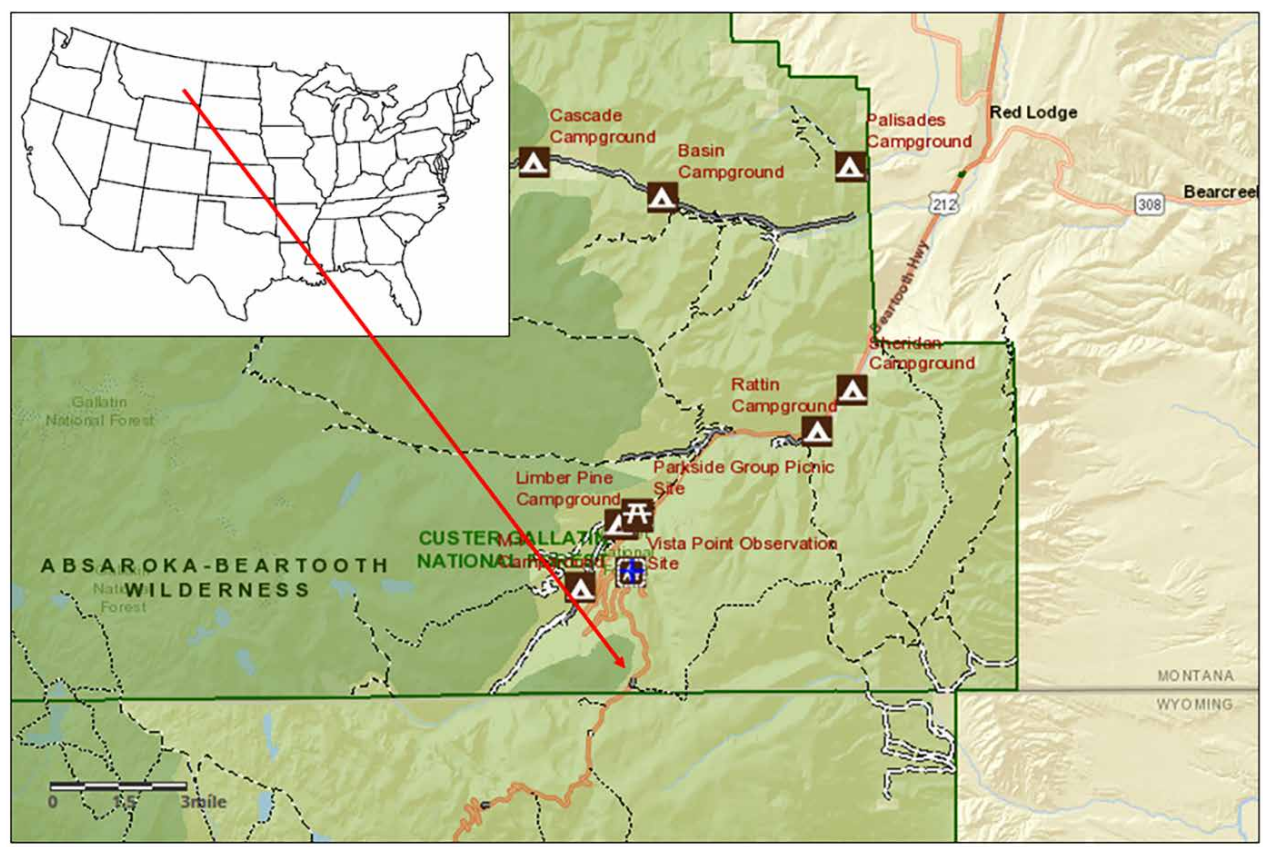

Fig. 1 Study area. The red arrow marks our study site. The map has been modified from the data available on https://www.fs.fed.us. 
chella), while the other part (with Caltha leptosepala and Gentiana algida) occurs with a Salix community type.

\section{Study species}

We studied three alpine plant species: Caltha leptosepala, Castilleja pulchella and Gentiana algida.

The white marsh marigold, Caltha leptosepala ( $R a-$ nunculaceae), is an erect, perennial herb with hairless and usually leafless stems, $5-10 \mathrm{~cm}$ tall, sometimes to $40 \mathrm{~cm}$, growing from short, erect rhizomes (Booth and Wright 1966). Leaves are basal, cordate, up to about $6 \mathrm{~cm}$ long, slightly longer than wide, rounded at tip, thick and waxy, almost entire to coarsely toothed with wavy edges. The petioles are shorter than the leaf blades to 2-3 times their length. Flowers are white, sometimes tinged bluish, saucer-shaped, 2-4 cm wide, with 5-15 showy, oblong to oval sepals and no petals. The flowers are usually solitary on stalks $3-10 \mathrm{~cm}$, rarely up to $20 \mathrm{~cm}$ tall, usually with a single leaf. Flowering occurs from May-August, depending on the elevation. Fruits are erect clusters of numerous pods (follicles), about $15 \mathrm{~mm}$ long. It is distributed from the subalpine to the tundra from 2600 to $3900 \mathrm{~m}$ a.s.l. (Lindeberg-Johnson 1981). The species occurs from Alaska to Colorado, Utah, Arizona, and western to north-eastern Nevada (http://montana.plant-life. org). In Montana, this species grows in wet subalpine and alpine places in western and southern parts of the state (Lesica 2012).

The Caltha leptosepala species complex is taxonomically unresolved, with authors of various regional floras recognizing different names and numbers of species (Wefferling and Hoot 2017, 2018). Integrating molecular, morphological, cytological, and geographic data, they described three species in the complex, restoring two species names, C. biflora and C. chionophila, in addition to recognizing C. leptosepala. Based on chloroplast and nuclear ribosomal phylogenies, they illustrated key morphological synapomorphies for the three Caltha species, assessed the usefulness of previously used morphological characters, and provided a dichotomous key for their field identification. Caltha leptosepala is a polyploid species and comprises a complex of hexaploids (6x), rare nonaploids $(9 \times)$, and dodecaploids $(12 \times)$. Wefferling et al. (2017) focused on the biogeography and evolutionary history of the complex. They delineated the geographic distribution and contact zones of the cytotypes, and investigated morphologies of cytotypes and subspecies. Genome size estimates from flow cytometry were used to infer cytotypes and a key morphological character, leaf length-to-width ratio, was measured to evaluate whether these dimensions are informative for taxon and/or cytotype delimitation. They found that Caltha leptosepala presents clear patterns of cytotype distribution at the large scale. Marked differences in morphology, range, and genome size were detected between the hexaploid subspecies, C. leptosepala subsp. howellii in the CascadeSierra axis and C. leptosepala subsp. leptosepala in the
Rocky Mountains. Sympatry between cytotypes in the Cascades and a parapatric distribution in the Northern Rockies suggest unique origins and separate lineages in the respective contact zones.

Caltha leptosepala is a hermaphrodite pollinated by bees, beetles, and flies (https://pfaf.org). The species is one of the alpine herbs with a developmental preformation, i.e. the initiation of leaves and/or flowers one or more growing seasons before they mature, which is common among alpine and arctic tundra plant species (Mark 1970). Aydelotte and Diggle (1997) studied a developmental preformation of Caltha leptosepala in detail and found that all structures in C. leptosepala are preformed. Leaves are initiated one or two growing seasons before they mature and flowers are initiated one growing season before maturation. The features of development and architecture in C. leptosepala, however, appear to differ from the determinate growth patterns of other exclusively preforming species, and may allow within-season variability in the seasonal development and maturation of structures. Cohorts of leaves initiated are asynchronous with maturation cohorts, and each year the number of leaf primordia per plant at snowmelt exceeds the number to mature aboveground. Therefore, some flexibility in whether leaves complete a 2 -yr or 3-yr developmental trajectory might occur. Plasticity in reproductive phenotype might also occur via the process of floral abortion.

Castilleja pulchella, the beautiful Indian paintbrush, is a perennial herb in the family Orobanchaceae (Lesica 2012). Stems are 5-15 cm high, ascending, and more or less villous especially above. Leaves are 1-4 cm long, the lower entire and linear-lanceolate, the upper broader and 3-cleft, puberulent and slightly villous; lobes linear-lanceolate, attenuate; bracts elliptic, usually 3-cleft, the middle lobe broad and rounded, tinged with brownish, villous; calyx yellowish, tipped with brownish, about $18 \mathrm{~mm}$. long; the corolla is slightly exserted, with the galea $7 \mathrm{~mm}$. long and the lip $5 \mathrm{~mm}$. long, its lobes lanceolate, and obtuse. In Montana, Castilleja pulchella occurs in the southwest and south-central parts of the state (Lesica 2012). This species is intermediate between $C$. lutea and C. occidentalis (Barnhart 1907).

Tank and Olmstead (2008) studied Castillejinae phylogeny and suggested that the perennial habit evolved a single time from an annual ancestral lineage that persisted throughout the diversification of Castillejinae, contrary to classical interpretations of life history evolution in plants. They argued that the prevalence of polyploidy among perennial Castilleja species, perenniality may have played an important role in the origin and establishment of polyploidy in Castilleja.

As many other Castilleja species, flowers of Castilleja pulchella are pollinated by bumblebees. Bauer (1983) studied relationships between several alpine species, including Castilleja pulchella, and ten bumblebees species during his research conducted on the Beartooth Plateau. 
Gentiana algida, the white gentian, whitish gentian or Arctic gentian, is a glabrous perennial plant with short rhizomes (Lesica 2012). They have one to several leafy and hairless stems, usually $5-20 \mathrm{~cm}$ tall. Dark green leaves are hairless, about 5-10 $\mathrm{mm}$ broad, the basal ones linear- to lance-shaped, 4-12 cm long. Lance-shaped leaves about $3-5 \mathrm{~cm}$ long are growing opposite, in 3-5 pairs. Flowers are funnel-shaped, usually in terminal pairs. The corolla is $35-50 \mathrm{~mm}$ long, white or pale yellowish, with five short pointed lobes, with a purple-blotched area from the back of each lobe nearly to the calyx and with a lengthwise fold between each lobe. The calyx is narrowly funnel-shaped, about $2 \mathrm{~cm}$ long, usually purplish-blotched, the tube squared off between the lobes, which are almost equal, linear to lance-shaped, slightly keeled, from half as long to almost equal the tube length. The species flowers from June-August. Fruits are capsules 3-4 cm long. The species grows in moist but well-drained sites in the alpine zone from Colorado and Utah to Alaska, and also in east Siberia and the Himalayas. In Montana, the species occurs the south-central and southwestern parts of the state (Lesica 2012). Along with many other gentians, secondary metabolites and medical effects of extracts from this species were studied (Tan et al. 1997; Khobrakova et al. 2017).

Thunderstorms with hails and summer snow showers are common in alpine regions where Gentiana algi$d a$ occurs. The closure of the upright, tubular flowers of this species were observed during the frequent afternoon thunderstorms characteristic of the central and southern Rocky Mountains (Bynum and Smith 2001). Flowers closed within minutes of an approaching thunderstorm and reopened after direct sunlight returned. The authors experimentally tested this behavior and found that manually opened flowers had substantial losses of pollen and reductions in female fitness also occurred. They supposed that corolla closing and opening in G. algida associated with frequent summer thunderstorms may be a behavioral adaptation that improves both paternal and maternal reproductive effort.

\section{Data collection and analyses}

We used the USDA plant species database (https:// plants.usda.gov) and specimens housed at the Herbarium at the University of Montana, Missoula to preselect the Line Creek Plateau RNA as a suitable site for study of three target species: Caltha leptosepala, Castilleja pulchel$l a$ and Gentiana algida. We visited the Line Creek Plateau RNA between August 21-23, 2018 and found sufficiently large populations of all three species.

We randomly selected ten individuals of each species, i.e. we threw a little ball over our head and chose the nearest plant, and recorded the following plant traits to describe their habitat and phenology status.
Each Caltha leptosepala plant was characterized by (1) size of the rosette in $\mathrm{cm}$. We collected two diameter measurements and averaged them. We did not press a rosette during measurement, and hence measured only the natural size of each rosette; (2) number of leaves in the rosette; and (3) the maximum width and length $(\mathrm{mm})$ of the youngest well-developed leaf in the rosette. The maximum length of the leaf was measured from the tip of the leaf to the tip of a cordate leaf lobe, not including the petiole; (4) the highest flowering stem in $\mathrm{cm}$; and (5) the number of buds/opened flowers/old flowers/ripe fruits/ immature fruits, i.e. phenological phases I-V (Fig. 2). We also measured the height of other stems (if they were present) and recorded the total number of flowers and fruits on each measured stem.

Castilleja pulchella does not have a basal rosette and we measured only (1) height of the highest stem; (2) the maximum width and length $(\mathrm{mm})$ of the most well-developed leaf on the tallest stem; and (3) the number of buds/opened flowers/old flowers/ripe fruits/immature fruits, i.e. phenological phases I-V (Fig. 3). For other stems (if they were present) we measured the height $(\mathrm{cm})$ and recorded the total number of flowers and fruits.

Gentiana algida plants form compact rosettes, or a group of several rosettes, with many overlapping linear-to lance-shaped leaves, and we could not count all of them without causing damage to the plants. We thus measured (1) the size of each rosette or group of rosettes $(\mathrm{cm})$, taking two diameter measurements of each plant and averaging them; (2) the maximum width and length $(\mathrm{mm})$ of the newest well-developed leaf on the highest stem; (3) the highest flowering stem $(\mathrm{cm})$ and (4) counted the number of buds/opened flowers/old flowers/ripe fruits/immature fruits, i.e. phenological phases I-V (Fig. 4). For other stems (if they were present) we measured the height $(\mathrm{cm})$ and recorded the total number of flowers and fruits.

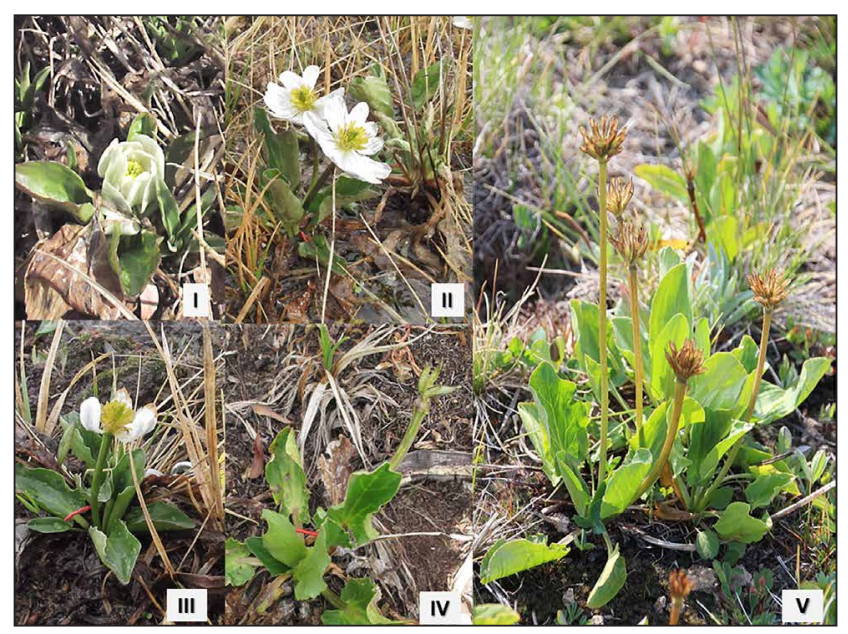

Fig. 2 Five phenological phases of Caltha leptosepala. I - a flower bud; II - an open flower; III - an old flower, which has already finished its flowering but fruits are not presented yet; IV - a green, immature fruit; $\mathrm{V}$ - a ripe fruit. 


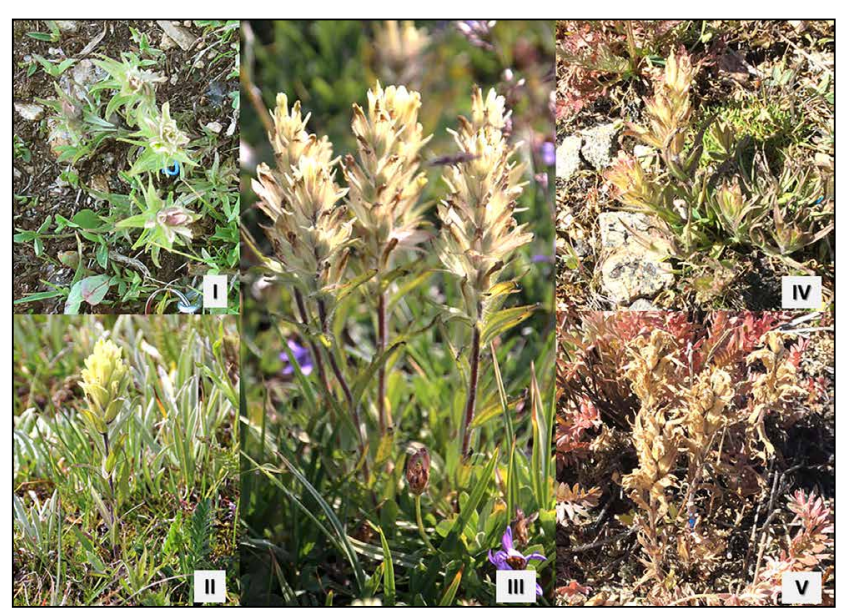

Fig. 3 Five phenological phases of Castilleja pulchella. I - a flower bud; II - an open flower; III - an old flower, which has already finished its flowering but fruits are not presented yet; IV - a green, immature fruit; $\mathrm{V}$ - a ripe fruit. The pictures show plants with a prevailing proportion of flowers of the selected phenological phases.

We also calculated the total number of stems, average height of stems and total number of flowers and fruits on each plant. We used the analysis of variation in STATISTICA 12 (Anonymous 2012) to compare phenological phases of each species and we used MS Excel for testing correlations between measured plant traits. Logarithmic transformation $\log (\mathrm{x}+1)$ was used to standardize data.

\section{Results}

We visited our study site on the Line Creek Plateau for three days in August 2018 and measured ten individuals of three target species (Caltha leptosepala, Castilleja pulchella and Gentiana algida) to optimise our methodology. The study species differ in their habits and plant traits (Table 1).

Two of the ten measured Caltha plants were sterile, without flowering stems. Four flowering Caltha plants had one flowering stem and four others had two flowering stems. Each flowering stem carried only one flower.

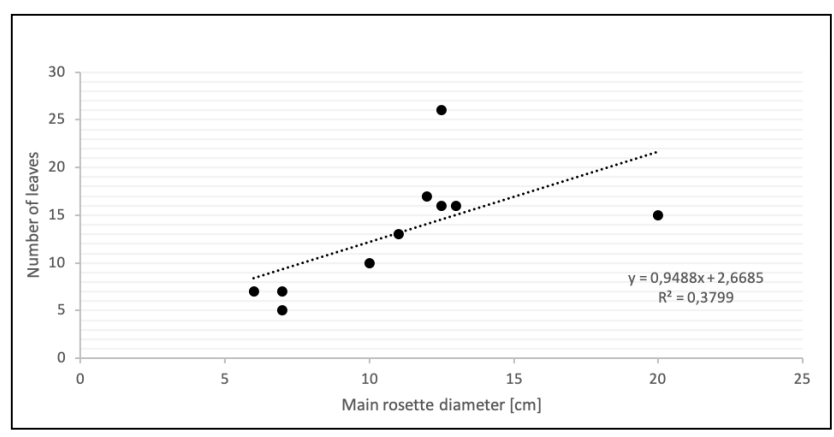

Fig. 5 Caltha leptosepala. Correlation between size of the main rosette and the number of leaves.

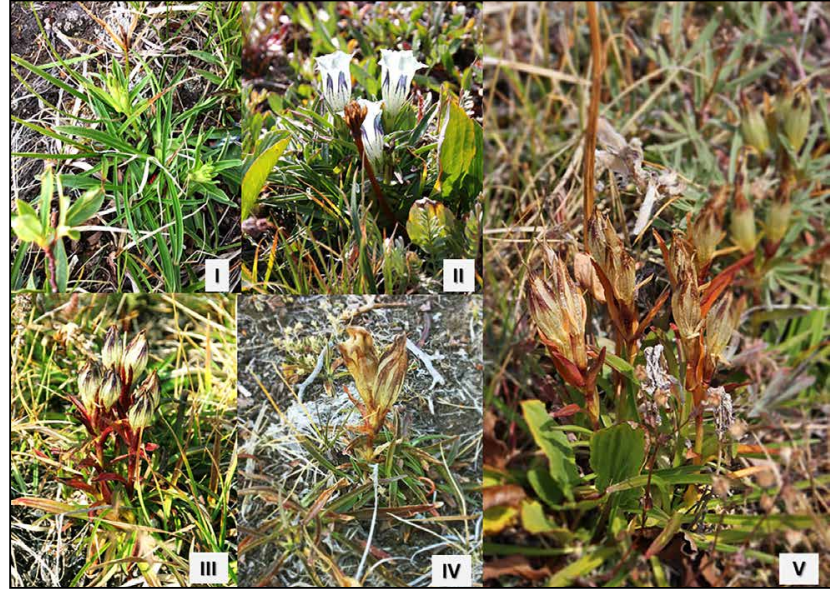

Fig. 4 Five phenological phases of Gentiana algida. I - a flower bud II - an open flower; III - an old flower, which has already finished its flowering but fruits are not presented yet; IV - a green, immature fruit; $\mathrm{V}$ - a ripe fruit; with a partly opened capsule. The pictures show plants with a prevailing proportion of flowers of the selected phenological phases.

Caltha plants differed in the size of their leaf rosettes. The average size of the main rosette was $11.10 \mathrm{~cm}$ in diameter and the plants had an average of 13.2 leaves. The smallest plant had a rosette only $6 \mathrm{~cm}$ in diameter and only seven leaves, while the largest plant had a rosette $20 \mathrm{~cm}$ in diameter and 15 leaves. We also measured a plant with 26 leaves that had a rosette only $13 \mathrm{~cm}$ in diameter. We found a slightly positive correlation between the size of the main rosette and the number of leaves (Fig. 5). The areas of the youngest well-developed leaves varied between $1,080-2,660 \mathrm{~mm}^{2}$ and there were no correlations between this leaf area and the size of rosettes, nor between this leaf area and the number of leaves in the rosette. We found a positive correlation between plant leaf area, calculated as the number of leaves in the main rosette ${ }^{*}$ leaf area of the newest well developed leaf, and the number of flowers and fruits (Fig. 6).

Ten measured Castilleja plants had flowering stems. Some plants had only one flowering stem and the largest plant had seven flowering stems. Several plants also had some sterile stems without flowers. The height of the highest flowering stems varied between $6-16 \mathrm{~cm}$. The

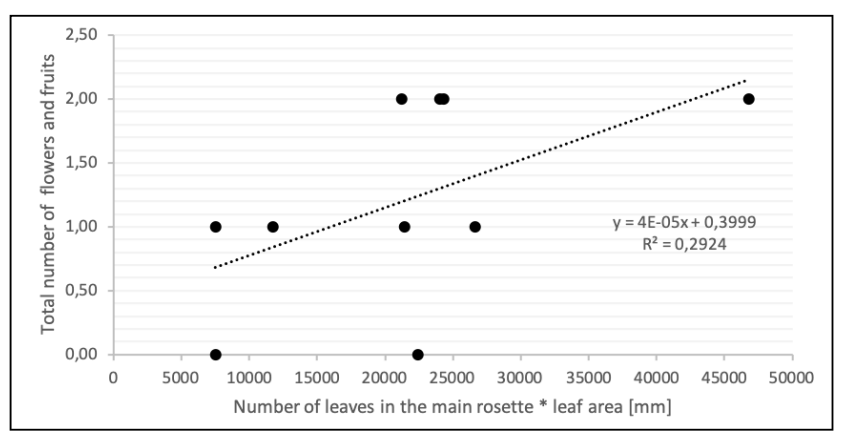

Fig. 6 Caltha leptosepala. Correlation between plant leaf area, i.e. number of leaves in the main rosette * leaf area of the newest well developed leaf, and the number of flowers and fruits. 


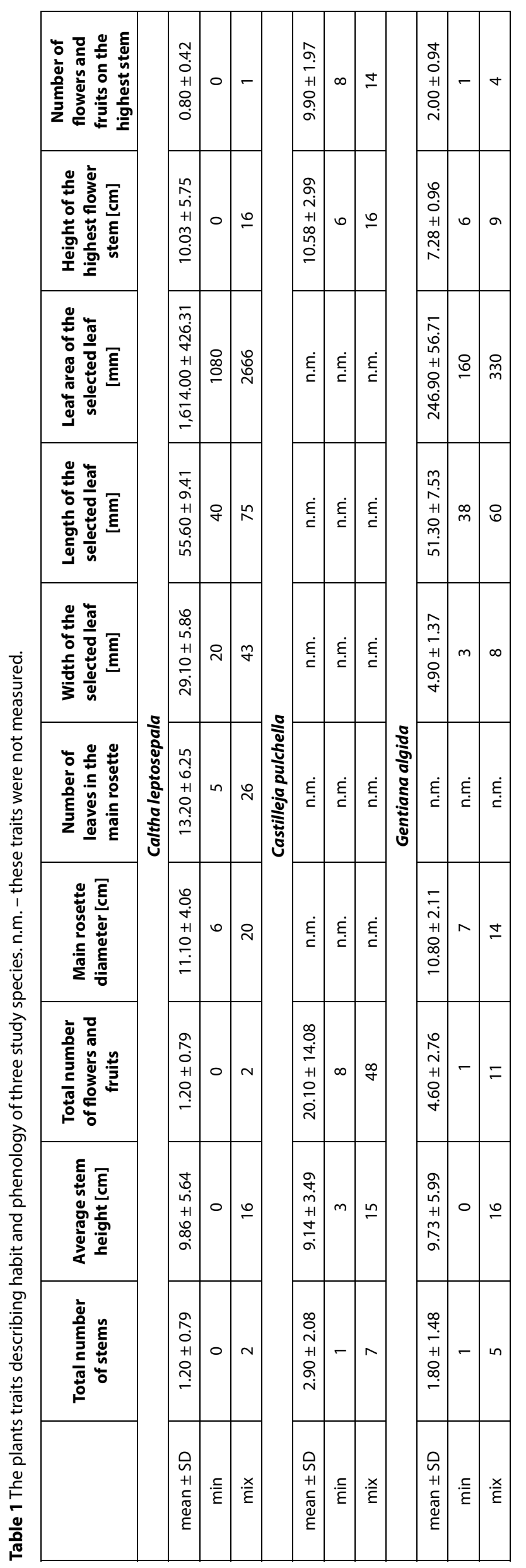

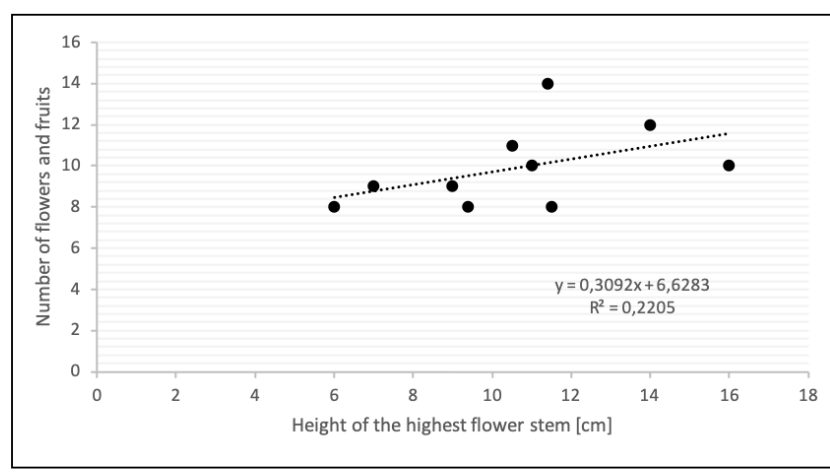

Fig. 7 Castilleja pulchella. Correlation between the height of the highest flower stem and the number of flowers and fruits.

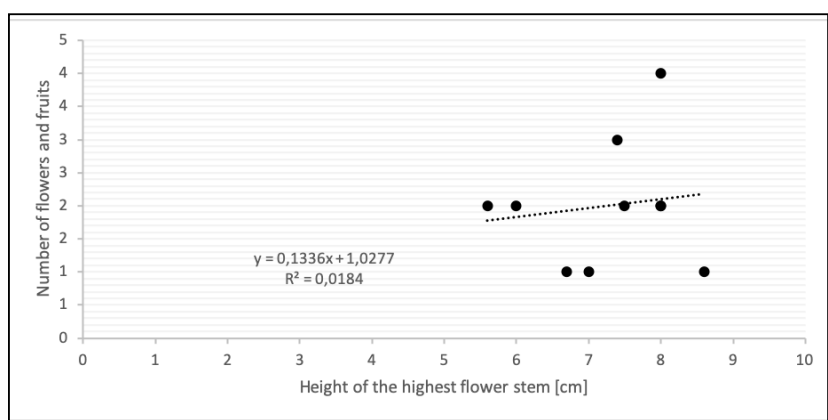

Fig. 8 Gentiana algida. Correlation between the height of the highest flower stem and the number of flowers and fruits.

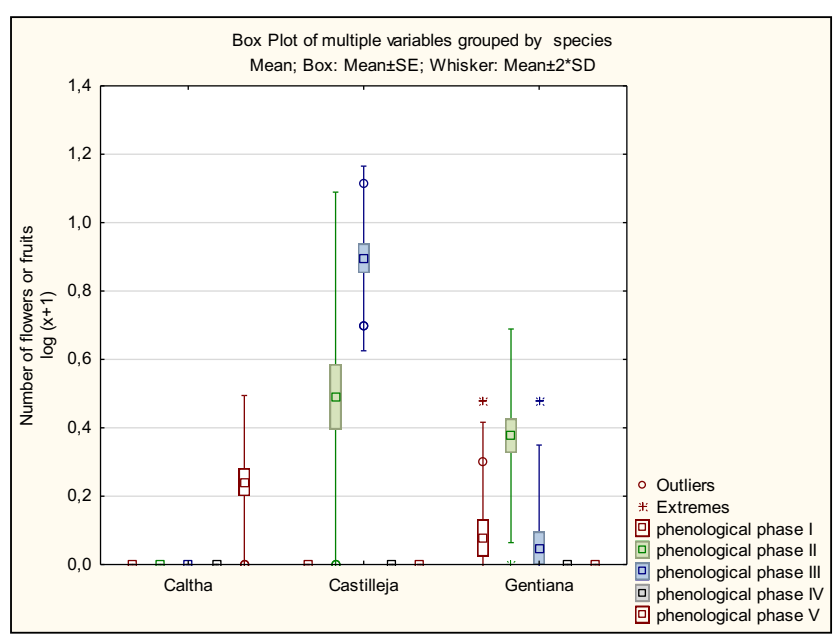

Fig. 9 Flowering phenology of three studied species.

flowering stems had between 7-14 flowers. The leaves of Castilleja were hairy and very small. We could not measure them without serious harm to them. We found a positive correlation between the height of the highest flower stem and the number of flowers and fruits (Fig. 7).

All measured Gentiana plants also had flowers. Six plants had two flowering stems and two had only one flowering stem. There were also two other Gentiana plants with four and five flowering stems, respectively. Flowering stems had between 1 and 4 flowers. We found a slightly positive correlation between the height of the highest flower stem and the number of flowers and fruits (Fig. 8). 
The three species were in different phenological phases at the time of this pilot study (Fig. 9). While all eight Caltha plants with flowering stems had ripe fruits, i.e. a phenological phase V, the highest stems of Castilleja plants had about one third of the flowers open, i.e. a phenological phase II, and two thirds of the flowers had finished their flowering but immature fruits were not present yet, i.e. a phenological phase III. Flowers on Gentiana plants were the youngest, least developed ones. The highest stems of two gentians carried buds, i.e. a phenological phase I. Most of the other flowers were opened, i.e. a phenological phase II, and only one flower was characterized as a flower of phenological phase III.

\section{Conclusions and Recommendations}

We found some positive correlations between the height of the highest stem and the number of flowers and fruits for two studied species, Castilleja pulchella and Gentiana algida. For Caltha leptosepala, we found a positive correlation between number of flowers and fruits and the plant leaf area, calculated as the number of leaves in the main rosette ${ }^{\star}$ leaf area of the newest well developed leaf. These results indicate a positive correlation between the photosynthetic capacity of the plants and their reproductive output. The energy partitioning has been studied and modeled in other plant species, for example in terrestrial orchids (Kindlmann and Balounová 1999).

Positive correlations between our measured plant traits could also indicate the idea to reduce a list of measured traits for each target plants, but the results represent only ten plants of each target species, and we do not support this idea. During testing of our methodology, we found that the time needed for measuring of the planned plant traits was acceptable. With the results from this preliminary study, we can assume that our methodology for monitoring of three target species (Caltha leptosepala, Castilleja pulchella and Gentiana algida) is appropriate and can be used for full season monitoring in 2019. The field protocols are in Appendix 1-3.

We visited our study site during the last week of August 2018 and found that three target species were in different phenological phases. Caltha plants were more or less withered and had ripened fruits, Castilleja were in peak flower, and Gentiana plants had some opened flowers and even some buds. We can assume that, despite a very short vegetation season, with snow melting about middle of June and the first snow coming again in the middle of September that these alpine species are not actively growing or reproducing throughout the whole season. There can be some phenological shifts within a large study site, because snow melts gradually, but generally, Caltha plants are very early and they can start flowering immediately after snow melt. Permanent rosettes of Gentiana plants are visible early after snow melt too but the first flowers do not appear until August. Castilleja plants begin flowering in the middle of summer (July). To better understand different plant species strategies, the start of the growing season must be defined (Odland 2011) and a full season of phenological data are important. To cover the full phenological variability of the study species, monitoring should be started as soon as possible after snow melt, i.e., the middle of June, and data should then be collected every 3 or 4 weeks. Studied individuals of three target species should be marked with unique markers, and well-developed leaves selected for measuring the leaf traits should be marked with a thin colored wire. The same marked leaf should be measured again during the second and other measurements, if possible. Only if the marker is lost or the leaf destroyed should a new well-developed leaf on the same rosette/stem be found and marked. A color photograph, showing a perpendicular projection of each plant and its label, should be taken during each monitoring visit.

\section{Acknowledgements}

We thank the US Forest Service, Beartooth Ranger District, Custer-Gallatin National Forest for permitting our research, and A. Watson for friendly logistic support. The Czech Grant Agency, grant number 17-12420S and the Ministry of Education, Youth and Sports of CR within the National Sustainability Program I (NPU I), grant number LO1415 provided the financial support.

\section{REFERENCES}

Anonymous (2012) STATISTICA, v. 12, StatSoft, Inc, Tulsa, OK, USA; Available from: http://www.statsoft.com.

Aydelotte AR, Diggle PK (1997) Analysis of developmental preformation in the alpine herb Caltha leptosepala (Ranunculaceae). Am J Bot 84: 1646-1657.

Bauer PJ (1983) Bumblebee pollination relationships on the Beartooth Plateau tundra of southern Montana. Am J Bot 70: 134-144.

Barnhart JH (1907) (ed) Bull Torr Bot Club Club 34: 40-41.

Booth WE, Wright JC (1966) Flora of Montana. Montana State Univ, Bozeman.

Bynum MR, Smith WK (2001) Floral movements in response to thunderstorms improve reproductive effort in the alpine species Gentiana algida (Gentianaceae) Am J Bot 88: 1088-1095.

Evenden AG, Moeur M, Shelly JS, Kimball SF, Wellner CA (2001) Research Natural Areas on National Forest System Lands in Idaho, Montana, Nevada, Utah, and Western Wyoming: A Guidebook for Scientists, Managers, and Educators. Gen. Tech. Rep. RMRS-GTR-69. Ogden, UT: U.S. Department of Agriculture, Forest Service, Rocky Mountain Research Station.

Fowler JF, Nelson BE, Hartman RL (2014) Vascular plant flora of the alpine zone in the southern Rocky Mountains, U.S.A. J Bot Res Inst Texas 8: 611-636.

Holub J (1967) Neue Namen innerhalb der Gattungen Gentianella Moench, Gentianopsis Ma und Comastoma (Wettst.) Tokoyuni. Folia Geobot Phytotaxon 2: 115-120. 
Khobrakova VB, Budaeva ER, Olennikov D, Zilfikarov IN (2017) Immunomodulation activity of extract of Gentiana algida Pall. Phar Chem J 51: 384-387.

Kindlmann P, Balounová Z (1999) Energy partitioning in terrestrial orchids - a model for assessing their performance. Ecol Model 119: 167-176.

Kolář F, Dušková E, Sklenář P (2016) Niche shifts and range expansions along cordilleras drove diversification in a high-elevation endemic plant genus in the tropical Andes. Mol Ecol 25: 4593-4610.

Körner C, Paulsen J, Spehn EM (2011) A definition of mountains and their bioclimatic belts for global comparison of biodiversity data. Alp Bot 121: 73-78.

Lesica P (2012) Manual of Montana vascular plants. BRIT Fort Worth, Texas, USA.

Lindeberg-Johnson M (1981) Ecological physiology of populations of Caltha leptosepala D.C. along altitudinal and latitudinal gradients in the central Rocky Mountains. Ph.D. dissertation. University of Colorado, Boulder, CO.

Mark AF (1970) Floral initiation and development in New Zealand alpine plants. New Zealand J Bot 8: 67-75.

McGill BJ, Enquist BJ, Weiher E, Westoby M (2006) Rebuilding community ecology from functional traits. Trends Ecol Evol 21: 178-185.

Odland A (2011) Estimation of the growing season length in alpine areas: effects of snow and temperatures. In: Schmidt JD (ed) Alpine environment: geology, ecology and conservation. Nova Science Pub, Inc. NY, USA. pp 85-134.

Pfitsch WA (1994) Morphological and physiological radiation in páramo Draba. In: Rundel PE, Smith AP, Meinzer FC (eds.) Trop Alp Env Cambridge, pp 151-165.

Schuettpelz E, Hoot SB (2004) Phylogeny and biogeography of Caltha (Ranunculaceae) based on chloroplast and nuclear DNA sequences. Am J Bot 91: 247-253.

Sheen AC, Brochmann C, Brysting AK, Elven R, Morris A, Soltis DE, Albert VA (2004) Northern hemisphere biogeography of
Cerastium (Caryophyllaceae): insights from phylogenetic analyses of noncoding plastid nucleotide sequences. Am J Bot 91: 943-952.

Sklenár P (2017) Seasonal variation of freezing resistance mechanisms in north-temperate alpine plants. Alp Bot 127: 31-39.

Sklenář P, Kučerová A, Macek P, Macková J (2012) The frost resistance mechanism in neotropical alpine plants is related to geographic origin. New Zealand J Bot 50: 391-400.

Sklenár P, Kučerová A, Macková J, Romoleroux K (2016) Temperature microclimates of plants in tropical alpine environment: How much does growth-form matter? Arct Antarct Alp Res 48: 61-78.

Tan RX, Hu J, Dong LD, Wolfender JL, Hostettmann K (1997) Two new secoiridoid glycosides from Gentiana algida. Planta Med 63: $567-569$.

Tank DC, Olmstead RD (2008) From annuals to perennials: Phylogeny of subtribe Castillejinae (Orobanchaceae). Am J Bot 96: 608-625.

USDA Forest Service (2001) Establishment Record for Line Creek Plateau Research Natural Area. USDA Forest Service, Northern and Rocky Mountain Regions, Missoula, Montana, USA.

Violle C, Navas ML, Vile D, Kazakou E, Fortunel C, Hummel I, Garnier E (2007) Let the concept of trait be functional! Oikos 116: 882-892.

Wefferling KM, Castro S, Loureiro J, Castro M, Tavares D, Hoot SB (2017) Cytogeography of the subalpine marsh marigold polyploid complex (Caltha leptosepala s.1.). Am J Bot 104: 271-285.

Wefferling KM, Hoot SB (2017) Species circumscription of the Caltha leptosepala polyploid complex (Ranunculaceae) based on molecular and morphological data. Phytotaxa 316: 201-223.

Wefferling KM, Hoot SB (2018) Dated phylogeography of western North American subalpine marsh marigolds (Caltha spp., Ranunculaceae): Miocene-Pliocene divergence of hexaploids, multiple origins of allododecaploids during the Pleistocene, and repeated recolonization of Last Glacial Maximum glaciated regions. J Biogeogr 45: 1077-1089. 

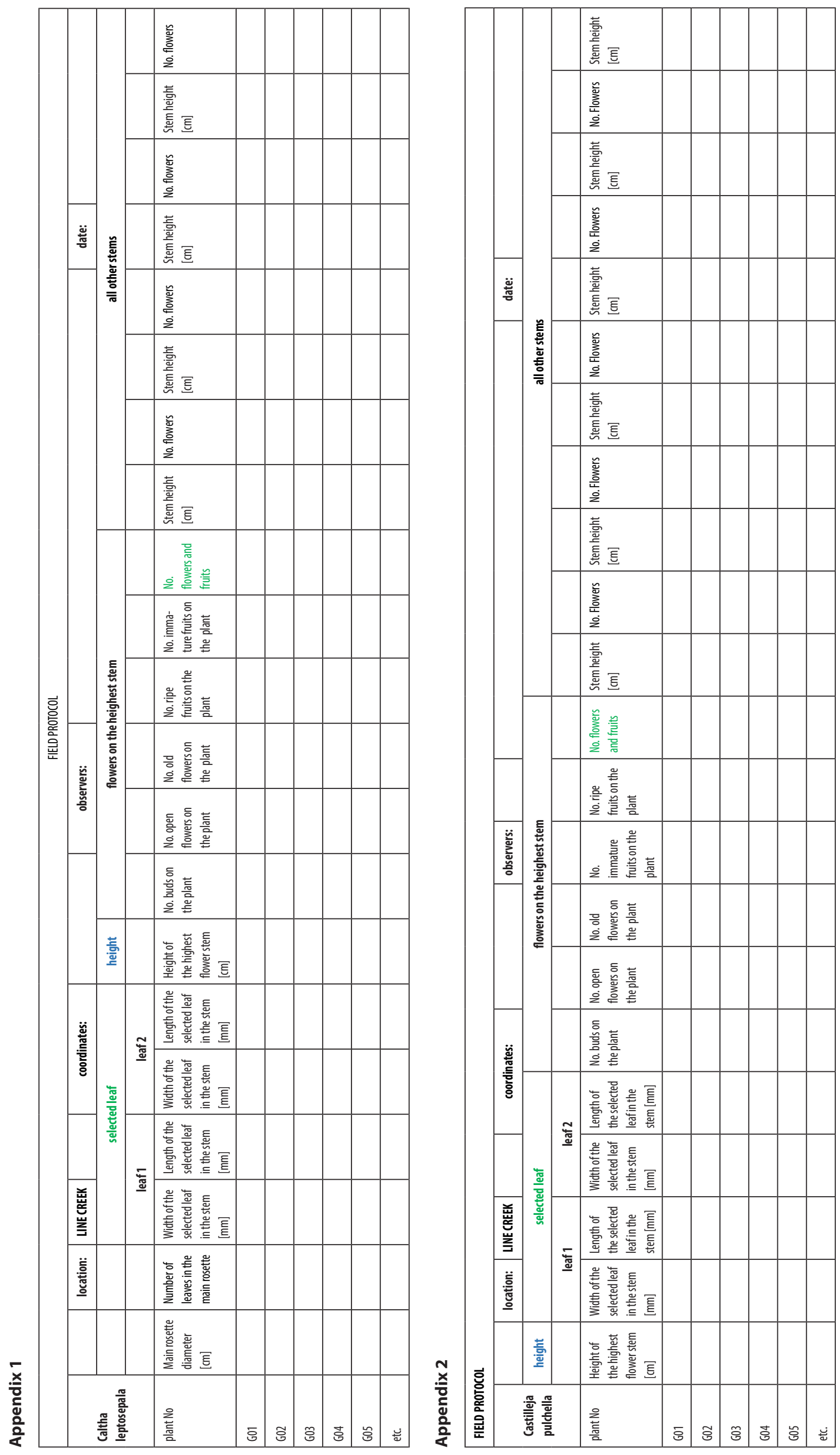


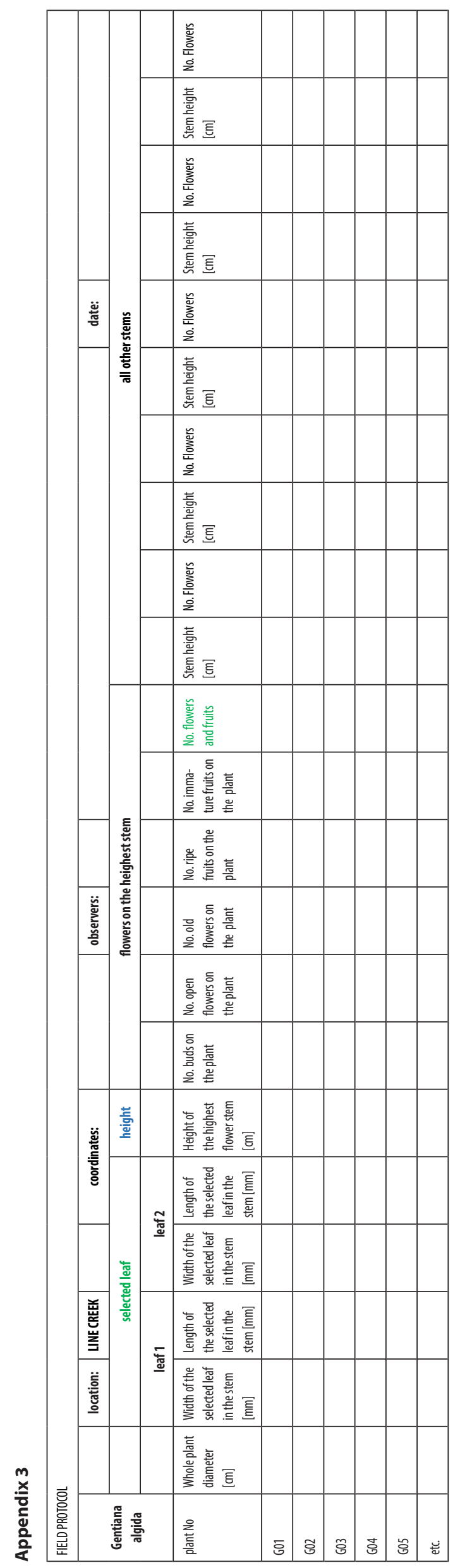

